\title{
Identifying experimental surrogates for Bacillus anthracis spores: a review
}

\author{
David L Greenberg, Joseph D Busch, Paul Keim, David M Wagner ${ }^{*}$
}

\begin{abstract}
Bacillus anthracis, the causative agent of anthrax, is a proven biological weapon. In order to study this threat, a number of experimental surrogates have been used over the past 70 years. However, not all surrogates are appropriate for B. anthracis, especially when investigating transport, fate and survival. Although B. atrophaeus has been widely used as a $B$. anthracis surrogate, the two species do not always behave identically in transport and survival models. Therefore, we devised a scheme to identify a more appropriate surrogate for $B$. anthracis. Our selection criteria included risk of use (pathogenicity), phylogenetic relationship, morphology and comparative survivability when challenged with biocides. Although our knowledge of certain parameters remains incomplete, especially with regards to comparisons of spore longevity under natural conditions, we found that $B$. thuringiensis provided the best overall fit as a non-pathogenic surrogate for $B$. anthracis. Thus, we suggest focusing on this surrogate in future experiments of spore fate and transport modelling.
\end{abstract}

\section{Background}

Bacillus anthracis, the causative agent of anthrax, has received much attention in the past decade due to its use in 2001 as a biological weapon distributed through the USA mail system. However, $B$. anthracis spores have been used as a weapon for close to 100 years and, historically, this pathogen was an important disease model [1]. This bacterium also provides a nearly perfect model of prokaryotic clonal evolution, with rare genomic recombination and extremely low levels of homoplasy [2]. The body of research acquired for B. anthracis provides key insights into its biology, epidemiology and the risks associated with its release into a civilian environment [3]. However, an important gap still remains in our empirical understanding of B. anthracis spore survival and mobility. As a result, it is necessary to examine and develop more accurate fate and transport models of anthrax spores in order to better understand public health risks and develop methods for emergency response to a mass release.

Mathematical fate and transport models provide a means of predicting the distribution of pathogenic particles after their release into air or water. Clearly, such information is an important asset in risk assessment

\footnotetext{
* Correspondence: Dave.Wagner@nau.edu

Center for Microbial Genetics and Genomics, Northern Arizona University, Flagstaff, AZ 86011-4073, USA
}

following a terrorist attack or a biological accident. Scenarios for intentional release into a civilian area include infecting the water supply or releasing aerosolized spores $[4,5]$. In a 1970 report, the World Health Organization predicted that $50 \mathrm{~kg}$ of spores released upwind of 500,000 civilians would result in 95,000 fatalities; likewise, a single subway attack could lead to over 10,000 deaths if carried out during rush hour [6]. Model scenarios and the 2001 events demonstrate that non-targeted individuals are also vulnerable. However, models may lack predictive power if their critical parameters are not based on real world values. Therefore, it is necessary to collect experimental data that will lead to greater model accuracy of spore behaviour. For example, our laboratory group is performing experiments to measure attenuation values for spore survivability in natural and artificial environments (such as water, soil and fomites). These and other experiments will help to validate the predictions of current mathematical models, thereby increasing model accuracy and improving our response to natural, accidental or intentional releases of anthrax.

Fully virulent $B$. anthracis must be handled under biosafety level (BSL)-3 conditions and requires secure containment. Therefore, we cannot experimentally release this organism into the environment nor use it in experiments outside of a BSL3 facility. In order to conduct experiments that inform release models, we must use a 
non-pathogenic bacterium that can accurately represent B. anthracis. Surrogates of this type have been used for many years in military release experiments, water supply studies and food protection assessment. However, little attention has been focused on the criteria used to select surrogates. Our synthesis makes use of existing empirical evidence to present an informed decision for the best choice of a $B$. anthracis surrogate.

\section{History of surrogate use for $B$. anthracis}

Before selecting an appropriate surrogate for B. anthracis, it is useful to review the history of surrogate use for this organism. This information, though anecdotal in some cases, provides valuable information useful for surrogate selection such as (1) comparative survival and behavioural data, (2) an initial list of potential surrogate candidates and (3) baseline data to compare against current experiments. Over the years a number of surrogates have been used, including an attenuated $B$. anthracis strain (Sterne) and several phylogenetic relatives: $B$. atrophaeus (formerly B. globigii and B. subtilis niger $[7,8])$, B. cereus, B. megaterium, B. mycoides, B. subtilis, B. thuringiensis and Geobacillus (Figure 1). Table 1 indicates the number of times each has been utilized in published studies. B. atrophaeus has been employed most frequently; $B$. cereus, $B$. subtilis and $B$. thuringiensis have been used moderately; and the others have been used just a few times (B. megaterium, B. mycoides and Geobacillus).

Both the USA and Japanese governments used pathogenic simulants in biological warfare test studies. For example, Yoshi Iishi of Japan confessed after World War II to using B. anthracis surrogates in his biological warfare programme, which was initiated in 1935 [9]. The USA began using B. atrophaeus as their major nonpathogenic surrogate for B. anthracis in July of 1943 at
Camp Detrick [9]. This surrogate has been used for many experiments in order to ascertain potential outcomes of using anthrax as a biological weapon [10-12]. In 1949 the USA Army experimentally sprayed B. atrophaeus and Serratia marcescens over the coastal population centers of Hampton, Virginia and San Francisco, California [9]. B. atrophaeus was also disseminated in Greyhound bus and New York subway terminals via covert spray generators hidden in briefcases during the mid-1960 s [11]. More recent work at national laboratories has emphasized the detection and identification of spores in the environment.

The earliest in-depth comparison of related Bacillus species was done by Schneiter and Kolb [13,14], who tested heat processing methods to destroy 'industrial' spores of B. anthracis, B. subtilis and B. cereus found on shaving brush bristles. Brazis et al. [15] made a direct comparison of the effect of free available chlorine on $B$. anthracis and B. atrophaeus spores and found that $B$. atrophaeus was more resistant to chlorine. In these early works, no mention is made of the potential for these species to be used as B. anthracis surrogates. However, their results provide valuable comparative data (for example, B. atrophaeus is more resistant to chlorine and therefore is a conservative surrogate for estimating B. anthracis survival in tap water).

More recent experiments have examined the effects of various environmental challenges and disinfectants on B. anthracis surrogates, including studies of food protection or decontamination in the wake of a release event. Faille et al. [16] used B. thuringiensis as a non-pathogenic representative for $B$. cereus and indicated that $B$. thuringiensis has been used in this capacity for many years. Others have used B. atrophaeus, B. thuringiensis, $B$. cereus and B. subtilis to examine decontamination strategies using various bactericidal compounds such as

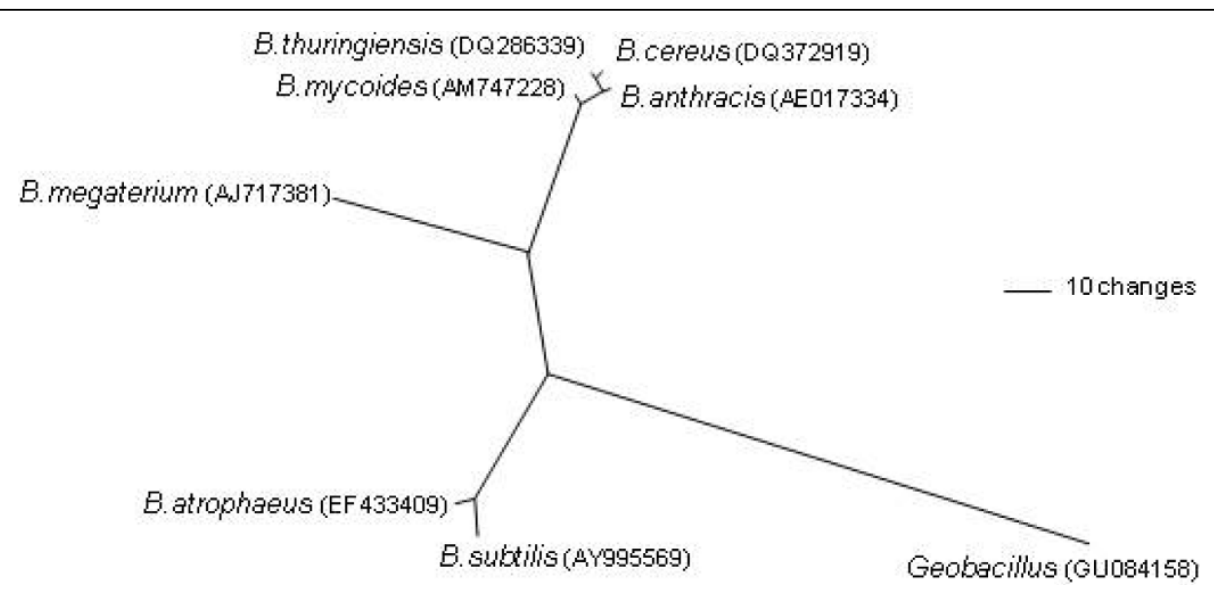

Figure 1 Unrooted phylogenetic tree of Bacillus anthracis and potential near-neighbour surrogates. Reconstruction is based on neighbour-joining analysis of $16 \mathrm{~s}$ rRNA gene sequences using Jukes-Cantor correction. GenBank accession numbers are provided in parentheses. 
Table 1 Number of historical uses for each potential surrogate with references

\begin{tabular}{lcl}
\hline Species* & No. of usest & References \\
\hline Bacillus atrophaeus & 40 & {$[15,17,18,27,29,34,40-42,48,50,52,54,68,71,72,75,76,78,83,86-88,94,95,101,102,104,107,109,112-115,174,208,219-222]$} \\
B. cereus & 29 & {$[22,26,40-43,48,54,58,59,65,66,68-70,72,73,77,82,88,95,103,104,174,213,223-226]$} \\
B. subtilis & 26 & {$[19,37,40,42-44,48,60,70,82,84,85,88,94,96,100,104-106,174,209,213,216,219,224,226]$} \\
B. thuringiensis & 26 & {$[16,22,26,27,40-43,48,58,60,66,68,72,81,82,88,94,95,99,100,111,174,192,227,228]$} \\
B. anthracis Sterne & 20 & {$[25,26,40,43,48,49,58-60,68,72,75,81,103,174,213,223,224,226,229]$} \\
B. megaterium & 8 & {$[40-42,48,94,102,104,174]$} \\
B. mycoides & 4 & {$[43,60,72,226]$} \\
Geobacillus & 3 & {$[37,174,209]$} \\
\hline
\end{tabular}

*Strains not identified.

${ }^{\dagger}$ References through January 2010.

chlorine, hydrogen peroxide, dyes, neutral oxone chloride, formaldehyde, gluteraldehyde and antibiotics [15,17-43]. Additional decontamination methods used against these surrogates include ultraviolet irradiation [39,44-50], plasma [51], electron beam radiation [52,53] and heat [39,54-63].

B. anthracis stand-ins have also played an important role in evaluating the broad arsenal of techniques used to detect and identify bio-threat agents in the environment. At least 17 methods have been employed to detect spores of $B$. anthracis and its relatives, including: electron microscopy [64], atomic force microscopy [65-68], photothermal spectroscopy [69], microcalorimetric spectroscopy [70], biochip sensors [71,72], Raman spectroscopy [73], polymerase chain reaction methods [74-80], optical chromatography [81], differential mobility spectroscopy [82], laser induced breakdown spectroscopy [83-86], flow cytometry sorting [87], mass spectroscopy [88-96], proteomics [97,98], luminescence analysis [99], long-wave biosensors [100], lytropic liquid sensors [101] and fluorescent labelling [102-105]. Although most of these studies used B. anthracis directly, some included close relatives for comparisons of detectability across species.

Lastly, surrogates have played an important role in several types of aerosol studies. They have been used to evaluate electrical forces [106,107], examine the effect of filter material on bioaerosol collection [108] and to determine if bees could be deployed to detect anthrax spores in the air [109]. Other studies have used standins such as $B$. thuringiensis to test spore movement in aerial spray $[4,110,111]$, transport and deposition efficiency of spores in ventilation ducts [112], engineered aerosol production [113] and re-aerosolization of spores [114]. B. atrophaeus has been used to reproduce an anthrax letter event, demonstrating how an individual swine located $1.5 \mathrm{~m}$ from an opened letter inhaled $>21,000$ spores [115]. This is a lethal dose for humans exposed to $B$. anthracis and validates the significant biothreat of passive spore dispersion.
From the diverse experimental uses of anthrax surrogates during the last 70 years, it is obvious that non-pathogenic representatives are indispensable for conducting safe inquiries into the behaviour and mobility of pathogen spores. However, not all species are equally appropriate stand-ins for $B$. anthracis. In the remainder of this review we outline our selection criteria, present pertinent literature for surrogate selection in B. anthracis and identify gaps in our knowledge of a surrogate's ability to mimic the behaviour of this pathogen. Whenever possible, we present quantified values to provide robust justification of any surrogate to be used in future fate and transport experiments.

\section{Selection criteria}

We used several criteria for selection, including (1) the risk of use (pathogenicity), (2) genetic similarity to B. anthracis, (3) morphology and (4) response to various chemical and environmental challenges. Our initial list began with microbes in the family Bacillaceae that have been used as surrogates in the past. Practical attributes of potential surrogates are summarized in Table 2. It is important to select appropriate representatives with regard to the specific experiments one wishes to conduct. As an example, if we were interested in studying the disinfectant capacity of a substance we would use a surrogate that has greater survivability than our target organism. The results would then provide conservative estimates of appropriate disinfectant levels. In our case, we are interested in physical experiments of mobility in water and air media. Hence, we determined that the physical properties of the spores are of greatest interest, including size, shape, density, surface morphology, surface structure and surface hydrophobicity. Behavioural responses to stress and natural conditions are also relevant to spore survival.

\section{Surrogate pathogenicity}

The risks associated with surrogate use are of critical concern. Table 3 lists the biosafety designations for the 
Table 2 Practical attributes in surrogate selection

\begin{tabular}{ll}
\hline Attribute & Remarks \\
\hline Safety & Should not cause illness or infection in animals or plants \\
Ease of culture & Able to produce with standard microbiological methods in a reasonable timeframe and have reproducibility \\
History of use & Possibility of attaining comparative information from the literature and judging surrogate behaviour \\
Ease and speed of detection & Allows large numbers of samples to be processed for rapid feedback of results \\
Cost & Surrogate production and detection should not be excessive \\
Stability or persistence & No long-term persistence, or easily decontaminated \\
Practical for industrial testing & Should not damage equipment or processes \\
\hline
\end{tabular}

potential surrogates. Surrogates are typically used to replace a pathogen that, if used, would present a potential threat to public health. B. anthracis is classified as a BSL-3 organism and work must be conducted under highly contained conditions not suitable for fate and transport experiments. Ideally, an attenuated strain of $B$. anthracis would be a good surrogate because it should behave similarly to the pathogenic strains and pose little risk. However, our knowledge of plasmid exchange rates and the environmental effects of these strains remains very limited - they may still pose a risk despite being classified as BSL-2 organisms. In addition, detection of $B$. anthracis in the environment, even of an attenuated strain, could cause a public relations issue. Worse, released surrogates might mask a real attack or create high background positives and unnecessary emergency responses. Therefore, we feel that non-pathogenic B. anthracis strains are not good surrogates for fate and transport experiments.

Another surrogate of interest is $B$. cereus. This species is an opportunistic food-borne pathogen that can infect humans [116,117] and the CDC recommends the handling of the organism at BSL-2 standards. Although it is naturally found in the environment, additional releases of this potential pathogen are deemed unsafe. As such, this organism cannot be used as a replacement for $B$. anthracis in spore release studies. The same is true for B. megaterium and Geobacillus stearothermophilus, which are treated as BSL-2 organisms.

\begin{tabular}{|c|c|}
\hline Species & Biosafety laboratory rating \\
\hline Bacillus anthracis Ames & BSL 3 \\
\hline B. anthracis Sterne & BSL-2 \\
\hline B. cereus & $\mathrm{BSL}-2$ \\
\hline B. megaterium & BSL-2 \\
\hline B. atrophaeus & BSL-1 \\
\hline B. subtilis & BSL-1 \\
\hline B. thuringiensis & BSL-1 \\
\hline Geobacillus stearothermophilus & BSL-2 \\
\hline
\end{tabular}

BSL, biosafety level.
The other potential surrogates, including $B$. atrophaeus, B. mycoides, B. subtilis and B. thuringiensis, are not typically regarded as potential human pathogens or select agents. They are BSL- 1 organisms and are safe candidates. B. thuringiensis is used as an insecticide throughout the world, and has been shown to pose no health risk to humans in some studies [118,119]. Infections do occasionally occur, however. These include a case from using commercial $B$. thuringiensis var. kurstaki [120], a wound infection identified as B. thuringiensis strain 97-27 [74,121], and an isolate recovered from a gastrointestinal illness [122]. That said, the overall the use of most $B$. thuringiensis strains appears to be safe and this species provides a good potential surrogate for $B$. anthracis $[118,119]$. B. atrophaeus is commonly found in soil throughout the world, is considered nonpathogenic and has been used extensively as a surrogate for $B$. anthracis [40,123]. B megaterium and B. subtilis are also found in the soil and are non-pathogenic to humans. Based on safety concerns, most candidates except $B$. cereus could serve as a surrogate for B. anthracis.

\section{Genetics of the potential surrogates}

Genetic relationships are important when selecting a surrogate because, theoretically, a phylogenetic relative should be morphologically and behaviorally more similar and have comparable physical characteristics to the target organism. There have been many genetic studies that elucidate the phylogenetic relationships of organisms related to $B$. anthracis [74,98,124-143]. The results of these studies indicate that $B$. anthracis is most closely related to $B$. cereus, $B$. thuringiensis and $B$. mycoides, which are grouped together as the $B$. cereus group (Figure 1 ). In contrast, B. subtilis, B. atrophaeus, B. megaterium, and Geobacillus are more distant relatives of B. anthracis. As their chromosomal genomes are very similar, some authors have suggested that $B$. cereus, $B$. thuringiensis and $B$. anthracis are actually a single species separated only by different plasmid composition [130]. However, highly informative genetic markers such as single nucleotide polymorphisms can resolve $B$. anthracis from these near neighbor species [144,145]. The identification of 
closely related surrogates does not present a problem when these powerful genetic tools are used. The importance of genetic similarity on spore composition is demonstrated by the $B c l A$ gene, which is unique to the $B$. cereus group. This protein is found in the exosporium and helps determine the adhesive properties of the spore $[146,147]$. As B. atrophaeus and B. megaterium are lacking this gene, we would expect important changes in behavior compared to B. anthracis.

\section{Morphology of the potential surrogates}

Morphological characters are important to consider when choosing a surrogate because physical behaviours are the foundation of transport models. As stated earlier, genetic relatedness is a good indicator of morphological similarity, so we expect organisms within the $B$. cereus group to be morphologically similar to B. anthracis. Microscopy examination reveals few morphological features that can be used to definitively distinguish the various species from one another $[64,65,68]$. However, spores present measurable differences among surrogates, including the structure of the exosporium, the presence/ absence of filamentous appendages and size variation.

The spores of the $B$. cereus group all possess a specific type of exosporium surrounding the outer spore coat. It is a balloon-like sac that envelopes the spore, is made of crystal lattices and, typically, has a short nap of hair-like projections extending off the surface [64-68,146,148-154]. The exosporium can be highly variable, both among $B$. anthracis relatives [155-157] and within $B$. anthracis, as shown by differences between the Vollum and Sterne strains [158]. Some species also have long appendages that extend off the exosporium, known as filaments. $B$. cereus, $B$. megaterium and $B$. thuringiensis all possess filaments, whereas $B$. anthracis has none [64,149-152,158-161]. More distant relatives such as $B$. atrophaeus and B. subtilis have neither a nap nor filaments $[67,68,152,162]$. Likewise, $B$. atrophaeus and $B$. megaterium have an atypical exosporium-like layer that is distinct but does not extend off the surface of the outer coat $[64,67,148,152,162-165]$. B. thuringiensis has a similar nap to $B$. anthracis but the presence or absence of filaments in B. thuringiensis is variable [152,166-168]. It is important to note that the exosporium is strongly hydrophobic [169] and that this chemical property may influence flow dynamics in aqueous solutions. Therefore, species with less hydrophobic spores (B. subtilis) are probably not appropriate simulants compared to the $B$. cereus group. As differences in exterior morphology will influence the mobility of pathogen spores in air and water, the investigation of these dynamics is a muchneeded focus of future research.

Size, shape and density of the spore are also considered important factors that can influence surrogate behavior in release experiments. The spores of the $B$. cereus group have similar ratios of length to width and similar diameters, whereas the spores of $B$. atrophaeus are smaller and those of $B$. megaterium are larger $[65,68,170,171]$. Although the difference in size is not great, it does exist and may require different coefficients for various model parameters (such as, Reynolds number, diffusion coefficient and sedimentation velocity) $[172,173]$. Spore volume is strongly correlated to density $(R=0.95)$ when spores are wet and in a moistened state the smaller spores of $B$. atrophaeus and B. subtilis are much more dense than $B$. anthracis [174]. Such differences are likely to affect the behaviour of these particles in air or water. Wet $B$. thuringiensis spores have densities and volumes within the range of $B$. anthracis, making this simulant a better match for the measurement of liquid dispersion. Interestingly, dry spore density is similar among the surrogates listed in Table 1, despite volume differences [174]. Thus, the right choice of surrogate appears to depend on the dispersion medium under consideration.

\section{Comparative survivability among surrogates}

Previous experiments comparing the survivability of various spore-formers provide valuable information to the surrogate selection process. Comparative experiments of spore survival under natural conditions or exposure to heat, ultraviolet and chemical disinfectants can illuminate which species may behave similarly to $B$. anthracis in experiments. In this section we review the literature for comparative spore survival.

Quantitative data relating inactivation kinetics of the natural survival of spores would be of great value when comparing potential surrogates. Unfortunately, most of the available data are qualitative. Past studies with B. anthracis have revealed that spores may survive for years under natural conditions [175-190]. The data are mostly qualitative, not directly comparable, and primarily exist only for $B$. anthracis. Experimental evidence that quantifies survival rates in both the short and long term are missing. Several studies examined the attenuation rate of $B$. thuringiensis spores on leaves, soil and snow [191-197]; B. cereus was included in a survival study measuring the effects of soil $\mathrm{pH}$, moisture, nutrients and presence of other microbes [198]. In addition to two aerosol field studies [110,199], we found no other studies that investigated natural attenuation rates of the potential surrogates for B. anthracis or that compared several species at once. Another drawback to using these data is that spore behaviour is variable due to factors such as purification method, sporulation conditions and strain type, and in many of these studies different purification protocols and strains are used, which makes direct comparisons of the values mostly pointless. 
Nevertheless these values do have some comparative information that can be used for surrogate selection. For example, natural attenuation values have been quantified for $B$. cereus and B. thuringiensis demonstrating that, after 135 days, the number of viable $B$. thuringiensis spores falls to about a quarter of the original inoculum [194]. The same may be true for B. anthracis but data are lacking. Although some spores remain active for a long time, the rate at which they lose viability is unknown, which suggests that additional experimental evidence is required to confirm the decay rates for B. anthracis spores and the potential surrogates.

Many experiments have been conducted that examine the effects of heat on spores [39,54,57,63,200-208]. However, very few studies have focused on quantifying differences in the survival of spores with regards to surrogate selection. More recent studies have compared the affect of heat on spores with the intention to understand differences among species. The main focus of most of these experiments is related to industrial sanitation, particularly disinfection in the food industry [58-60,62,209-211]. Montville and coworkers [60] have published the only study that specifically compares attenuation values among several surrogates. Whitney et al. [39] review some of the studies on the thermal survival of $B$. anthracis, whereas Mitscherlich and March [212] provide a very comprehensive review on the overall survival of $B$. anthracis and many of the potential surrogate candidates. However, it is apparent that the variability of $\mathrm{D}$ values (decimal reduction times) within species is large enough that we cannot make any robust decisions based upon this comparative information [60]. Rather, from these data we realize that each strain may behave differently with regards to survivability. As a result, each potential surrogate species should be compared directly with $B$. anthracis in future experimental studies.

Experiments to compare the effect of disinfectants can also be useful for examining parallels in spore resilience. Whitney et al. [39] reviewed many of the studies that have performed disinfectant trials on $B$. anthracis. Brazis et al. [15] compared the effects of chlorine on B. atrophaeus and B. anthracis spores and found B. atrophaeus survival to be a conservative indicator for $B$. anthracis survival. $B$. cereus spores reasonably simulate $B$. anthracis spore inactivation by peroxyacetic acid-based biocides, but are less reliable for hydrogen peroxide, sodium hypochlorite, and acidified sodium chlorite [213]. Rice et al. [26] examined the affect of chlorine on several $B$. anthracis strains and potential surrogates and found that $B$. thuringiensis behaviour was most similar to a virulent $B$. anthracis strain. However, they also found a difference between the attenuated and virulent B. anthracis strains, indicating that even very close organisms may behave differently when conditions vary. More recently, Sagripanti et al. [40] investigated the effects of various chlorides and other decontaminants on virulent $B$. anthracis and several potential surrogates on glass, metal, and polymeric surfaces.

Over the years many studies have focused on different bactericidal techniques for $B$. anthracis and their comparative effect on survival, including ultraviolet $[44,48-50,214]$ and various chemicals $[15,34,39,215]$. Two of the ultraviolet studies were geared toward surrogate selection. Nicholson and Galeano [44] validated $B$. subtilis as a good ultraviolet surrogate for B. anthracis using the attenuated Sterne strain. However, another study found B. subtilis spores were highly resilient to ultraviolet ionizing radiation when immersed in water and concluded this species would be a poor surrogate for B. anthracis [216]. Menetrez and coworkers [48] found that $B$. anthracis Sterne was more resistant to ultraviolet than other surrogates, including $B$. thuringiensis, B. cereus and B. megaterium. Therefore, the data remain equivocal for choosing a stand-in with similar ultraviolet survival characteristics.

The results from the literature search on survivability are useful, but must be used with caution when comparing surrogates. Several authors have noted the high variability observed between spore batches and experiments $[26,44]$. This variability makes the translation of results from different researchers difficult. Stringent testing of differences between strains can only take place when careful experimental designs are employed, including sporulation under identical conditions and strictly conserved methods for purification and survival estimates. The overall conclusions drawn from the results of previous survivability experiments suggest that any of our potential surrogates may behave similarly to B. anthracis. As a result, individual laboratory testing is also required in order to empirically validate a surrogate choice based on theoretical considerations.

\section{Choice of surrogate}

Our goal was to examine the various possible surrogates for $B$. anthracis, review the criteria for selecting an appropriate surrogate, compare the potential surrogates by these criteria and, ultimately, choose the most appropriate surrogate for our purposes. After examination of the first criteria, safety of use, we are left with $B$. atrophaeus, B. thuringiensis, B. megaterium and B. subtilis as potential surrogates. However, after further examination of genetic relatedness and the consequential morphological differences, $B$. thuringiensis emerges as the most appropriate candidate for a $B$. anthracis surrogate. This may be a surprising choice for some researchers, based on the traditional preference for B. atrophaeus. However, further examination of published comparisons 
Table 4 Gaps in our knowledge related to surrogate selection and model parameters

\begin{tabular}{ll}
\hline Gaps & Recommended action \\
\hline No quantitative comparisons of spore survival on fomites & Conduct experiments using steel, laminar, plastic and other surfaces \\
\hline No quantitative comparisons of spore survival in buffer/water & Conduct experiments across soil types \\
\hline No long-term studies & Conduct survival experiments in water or buffer \\
\hline Only one comparative study examining the effect of heat in various buffers & Reconfirm results \\
\hline Only one comparative study with UV & Reconfirm results \\
\hline Only a few studies with virulent Bacillus anthracis & Use virulent B. anthracis and compare directly to potential surrogates \\
\hline
\end{tabular}

also supports $B$. thuringiensis as a good surrogate for $B$. anthracis.

We recommend $B$. thuringiensis as the most appropriate surrogate based upon existing empirical data. As a result of the phenotypic similarity within the $B$. cereus group it will be important to utilize a $B$. thuringiensis strain that has a publically available genome sequence, such as $B$. thuringiensis serovar israelensis (ATCC 35646; GenBank No. AAJM01000000). This will allow for strain-specific markers to be identified $[217,218]$ which can be used as the basis for assays that can readily detect this strain and distinguish it from con-specifics as well as near neighbour species. We stress that additional experimental evidence is needed to confirm that $B$. thuringiensis and B. anthracis have similar behaviours. Data on spore survival and mobility are extremely lacking and we have identified several important knowledge gaps (Table 4). We have found only a few studies comparing spores from Bacillus species with the goal of surrogate validation and comparison $[26,40,44,48,60]$. We are aware of no studies that provide comparative survival of the surrogate candidates in soil or on different types of fomites, both under natural conditions and with heat, $\mathrm{pH}$ variance or UV radiation. In addition, there are no quantitative studies on the long-term survival of the spores in any medium. We also find very few studies that use virulent $B$. anthracis strains. The current literature suggests that there can be differences between the attenuated strains and the virulent strains. Therefore, in order to truly quantify and thereby confirm that our selected surrogate is the correct choice, we recommend conducting additional comparative experiments.

\section{Abbreviation}

BSL: biosafety level.

\section{Acknowledgements}

This study was supported by the Center for Advancing Microbial Risk Assessment, which is funded by the US Environmental Protection Agency Science to Achieve Results programme and the US Department of Homeland Security University Programs (grant R3236201).

\section{Authors' contributions}

DG and DW conceived the study. DG, JB, PK and DW drafted the manuscript. All authors read and approved the final manuscript.

\section{Competing interests}

The authors declare that they have no competing interests.

Received: 15 January 2010 Accepted: 1 September 2010 Published: 1 September 2010

\section{References}

1. Tournier JN, Ulrich RG, Quesnel-Hellmann A, Mohamadzadeh M, Stiles BG: Anthrax, toxins and vaccines: a 125-year journey targeting Bacillus anthracis. Expert Rev Anti Infect Ther 2009, 7:219-236.

2. Pearson T, Busch JD, Ravel J, Read TD, Rhoton SD, U'Ren JM, Simonson TS, Kachur SM, Leadem RR, Cardon ML, Van Ert MN, Huynh LY, Fraser CM, Keim P: Phylogenetic discovery bias in Bacillus anthracis using singlenucleotide polymorphisms from whole-genome sequencing. PNAS 2004, 101:13536-13541.

3. Turnbull PCB: Introduction: Anthrax history, disease and ecology. Anthrax. Current Topics In Microbiology And Immunology 2002, 271:1-19.

4. Levin DB, Valadares de Amorim G: Potential for aerosol dissemination of biological weapons: lessons from biological control of insects. Biosecurity and bioterrorism: Biodefense strategy, practice, and science 2003, 1:37-42.

5. Meinhardt PL: WATER AND BIOTERRORISM: Preparing for the Potential Threat to U.S. Water Supplies and Public Health. Annual Review of Public Health 2005, 26:213-237.

6. WHO Group of Consultants: Health Aspects of Chemical and Biological Weapons Geneva: WHO 1970.

7. Fritze $D$, Pukall R: Reclassification of bioindicator strains Bacillus subtilis DSM 675 and Bacillus subtilis DSM 2277 as Bacillus atrophaeus. Int J Syst Evol Microbiol 2001, 51:35-37.

8. Nakamura LK: Taxonomic Relationship of Black-Pigmented Bacillus subtilis Strains and a Proposal for Bacillus atrophaeus sp. nov. Int I Syst Bacteriol 1989, 39:295-300.

9. Regis E: The Biology of Doom New York: Henry Holt and Company 1999.

10. Carey LF, Amant DCS, Guelta MA, Proving E: Production of Bacillus Spores as a Simulant for Biological Warfare Agents. EDGEWOOD CHEMICAL BIOLOGICAL CENTER ABERDEEN PROVING GROUND 2004, 40.

11. Regis E: The Biology of Doom. The History of America's Secret Germ Warfare Project New York: Henry Holt \& Co 1999.

12. Stuart $A L$, Wilkening DA: Degradation of biological weapons agents in the environment: implications for terrorism response. Environ Sci Technol 2005, 39:2736-2743.

13. Kolb RW, Schneiter R: The germicidal and sporicidal efficacy of methyl bromide for Bacillus anthracis. J Bacterio/ 1950, 59:401-412.

14. Schneiter R, Kolb RW: Heat resistance studies with spores of Bacillus anthracis and related aerobic bacilli in hair and bristles. In Supplement No. 207 to the Public Health Reports Edited by: NPHS 1948, 1-24.

15. Brazis AR, Leslie JE, Kabler PW, Woodward RL: The inactivation of spores of Bacillus globigii and Bacillus anthracis by free available chlorine. Appl Microbiol 1958, 6:338-342.

16. Faille C, Dennin L, Bellon-Fontaine MN, Benezech T: Cleanability of stainless steel surfaces soiled by Bacillus thuringiensis spores under various flow conditions. Biofouling 1999, 14:143-151. 
17. Buttner MP, Cruz P, Stetzenbach LD, Klima-Comba AK, Stevens VL, Cronin TD: Determination of the efficacy of two building decontamination strategies by surface sampling with culture and quantitative PCR analysis. Appl Environ Microbiol 2004, 70:4740-4747.

18. Weber DJ, Sickbert-Bennett E, Gergen MF, Rutala WA: Efficacy of selected hand hygiene agents used to remove Bacillus atrophaeus (a surrogate of Bacillus anthracis) from contaminated hands. Jama 2003, 289:1274-1277.

19. Radziminski C, Ballantyne L, Hodson J, Creason R, Andrews RC, Chauret C: Disinfection of Bacillus subtilis spores with chlorine dioxide: a benchscale and pilot-scale study. Water Res 2002, 36:1629-1639.

20. Gorman SP, Scott EM, Hutchinson EP: Hypochlorite effects on spores and spore forms of Bacillus subtilis and on a spore lytic enzyme. $J$ Appl Bacteriol 1984, 56:295-303.

21. Wyatt $L R$, Waites WM: The effect of chlorine on spores of Clostridium bifermentans, Bacillus subtilis and Bacillus cereus. J Gen Microbiol 1975, 89:337-344.

22. Beuchat LR, Pettigrew CA, Tremblay ME, Roselle BJ, Scouten AJ: Lethality of chlorine, chlorine dioxide, and a commercial fruit and vegetable sanitizer to vegetative cells and spores of Bacillus cereus and spores of Bacillus thuringiensis. Ind Microbiol Biotechnol 2005, 32:301-308.

23. Young SB, Setlow P: Mechanisms of killing of Bacillus subtilis spores by hypochlorite and chlorine dioxide. J Appl Microbiol 2003, 95:54-67.

24. Cortezzo DE, Koziol-Dube K, Setlow B, Setlow P: Treatment with oxidizing agents damages the inner membrane of spores of Bacillus subtilis and sensitizes spores to subsequent stress. J Appl Microbiol 2004, 97:838-852.

25. Rose L, Rice EW, Jensen B, Murga R, Peterson A, Donlan RM, Arduino MJ: Chlorine inactivation of bacterial bioterrorism agents. Appl Environ Microbiol 2005, 71:566-568.

26. Rice EW, Adcock NJ, Sivaganesan M, Rose LJ: Inactivation of spores of Bacillus anthracis Sterne, Bacillus cereus, and Bacillus thuringiensis subsp. israelensis by chlorination. Appl Environ Microbiol 2005, 71:5587-5589.

27. Delcomyn CA, Bushway KE, Henley MV: Inactivation of biological agents using neutral oxone-chloride solutions. Environ Sci Technol 2006, 40:2759-2764.

28. Kreske $A C, R y u J H$, Beuchat LR: Evaluation of chlorine, chlorine dioxide, and a peroxyacetic acid-based sanitizer for effectiveness in killing Bacillus cereus and Bacillus thuringiensis spores in suspensions, on the surface of stainless steel, and on apples. Journal Of Food Protection 2006 69:1892-1903.

29. Szabo JG, Rice EW, Bishop PL: Persistence and decontamination of Bacillus atrophaeus subsp. globigii spores on corroded iron in a model drinking water system. Appl Environ Microbiol 2007.

30. Cross JB, Currier RP, Torraco DJ, Vanderberg LA, Wagner GL, Gladen PD: Killing of bacillus spores by aqueous dissolved oxygen, ascorbic acid, and copper ions. Appl Environ Microbiol 2003, 69:2245-2252.

31. Melly E, Cowan AE, Setlow P: Studies on the mechanism of killing of Bacillus subtilis spores by hydrogen peroxide. J Appl Microbiol 2002, 93:316-325.

32. Loshon CA, Melly E, Setlow B, Setlow P: Analysis of the killing of spores of Bacillus subtilis by a new disinfectant, Sterilox. J Appl Microbiol 2001, 91:1051-1058.

33. Marquis RE, Shin SY: Mineralization and responses of bacterial spores to heat and oxidative agents. FEMS Microbiol Rev 1994, 14:375-379.

34. Sagripanti JL, Bonifacino A: Comparative sporicidal effects of liquid chemical agents. Appl Environ Microbiol 1996, 62:545-551.

35. Sagripanti JL, Bonifacino A: Comparative sporicidal effect of liquid chemical germicides on three medical devices contaminated with spores of Bacillus subtilis. Am J Infect Control 1996, 24:364-371.

36. Young SB, Setlow P: Mechanisms of killing of Bacillus subtilis spores by Decon and Oxone, two general decontaminants for biological agents. $J$ Appl Microbiol 2004, 96:289-301.

37. Rogers JV, Sabourin CL, Choi YW, Richter WR, Rudnicki DC, Riggs KB, Taylor ML, Chang J: Decontamination assessment of Bacillus anthracis, Bacillus subtilis, and Geobacillus stearothermophilus spores on indoor surfaces using a hydrogen peroxide gas generator. J Appl Microbiol 2005, 99:739-748.

38. Armstrong G, Watson I, Stewart-Tull D: Inactivation of B. cereus spores on agar, stainless steel or in water with a combination of Nd: YAG laser and
UV irradiation. INNOVATIVE FOOD SCIENCE \& EMERGING TECHNOLOGIES 2006, 7:94-99.

39. Whitney EAS, Beatty ME, Taylor TH, Weyant R, Sobel J, Arduino MJ, Ashford DA: Inactivation of Bacillus anthracis spores. Emerging Infectious Diseases 2003, 9:623-627.

40. Sagripanti JL, Carrera M, Insalaco J, Ziemski M, Rogers J, Zandomeni R: Virulent spores of Bacillus anthracis and other Bacillus species deposited on solid surfaces have similar sensitivity to chemical decontaminants. Journal Of Applied Microbiology 2007, 102:11-21.

41. Demidova TN, Hamblin MR: Photodynamic inactivation of Bacillus spores, mediated by phenothiazinium dyes. Appl Environ Microbiol 2005, 71:6918-6925.

42. Demidova TN, Hamblinl MR: Anthrtax surrogate spores are destroyed by PDT mediated by phenothiazinium dyes. In Prodceedings of SPIE; Bellingham, WA Edited by: Kessel D 2005.

43. Montville TJ, De Siano T, Nock A, Padhi S, Wade D: Inhibition of Bacillus anthracis and potential surrogate bacilli growth from spore inocula by nisin and other antimicrobial peptides. Journal Of Food Protection 2006, 69:2529-2533.

44. Nicholson WL, Galeano B: UV resistance of Bacillus anthracis spores revisited: validation of Bacillus subtilis spores as UV surrogates for spores of B. anthracis Sterne. Appl Environ Microbiol 2003, 69:1327-1330

45. Setlow P: Resistance of spores of Bacillus species to ultraviolet light. Environ Mol Mutagen 2001, 38:97-104.

46. Myasnik M, Manasherob R, Ben-Dov E, Zaritsky A, Margalith Y, Barak Z: Comparative sensitivity to UV-B radiation of two Bacillus thuringiensis subspecies and other Bacillus sp. Curr Microbiol 2001, 43:140-143.

47. Griego VM, Spence KD: Inactivation of Bacillus thuringiensis spores by ultraviolet and visible light. Appl Environ Microbiol 1978, 35:906-910.

48. Menetrez MY, Foarde KK, Webber TD, Dean TR, Betancourt DA: Efficacy of UV irradiation on eight species of Bacillus. Journal Of Environmental Engineering And Science 2006, 5:329-334.

49. Blatchley ER, Meeusen A, Aronson Al, Brewster L: Inactivation of Bacillus spores by ultraviolet or gamma radiation. Journal Of Environmental Engineering-Asce 2005, 131:1245-1252.

50. Rice JK, Ewell M: Examination of peak power dependence in the UV inactivation of bacterial spores. Appl Environ Microbiol 2001, 67:5830-5832.

51. Lee K, Paek KH, Ju WT, Lee Y: Sterilization of bacteria, yeast, and bacterial endospores by atmospheric-pressure cold plasma using helium and oxygen. J Microbiol 2006, 44:269-275.

52. Helfinstine SL, Vargas-Aburto C, Uribe RM, Woolverton CJ: Inactivation of Bacillus endospores in envelopes by electron beam irradiation. Appl Environ Microbiol 2005, 71:7029-7032.

53. Niebuhr SE, Dickson JS: Destruction of Bacillus anthracis strain Sterne 34F2 spores in postal envelopes by exposure to electron beam irradiation. Lett Appl Microbiol 2003, 37:17-20.

54. Schneiter R, Kolb RW: Heat resistance studies with spores of Bacillus anthracis and related aerobic bacilli in hair and bristles. In Supplement No. 207 to the Public Health Reports Edited by: Public Health Service N 1948, $1-24$.

55. Paik WW, Sherry EJ, Stern JA: Thermal Death Of Bacillus Subtilis Var Niger Spores On Selected Lander Capsule Surfaces. Applied Microbiology 1969, 18:901.

56. Beaman TC, Gerhardt P: Heat resistance of bacterial spores correlated with protoplast dehydration, mineralization, and thermal adaptation. Appl Environ Microbiol 1986, 52:1242-1246.

57. Palop $\mathrm{A}$, Manas $\mathrm{P}$, Condon $\mathrm{S}$ : Sporulation temperature and heat resistance of Bacillus spores: A review. Journal Of Food Safety 1999, 19:57-72.

58. Rice EW, Rose $L$, Johnson CH, Boczek LA, Arduino MJ, Reasoner DJ: Boiling and Bacillus spores. Emerg Infect Dis 2004, 10:1887-1888.

59. Novak JS, Call J, Tomasula P, Luchansky JB: An assessment of pasteurization treatment of water, media, and milk with respect to Bacillus spores. Journal Of Food Protection 2005, 68:751-757.

60. Montville TJ, Dengrove R, De Siano T, Bonnet M, Schaffner DW: Thermal resistance of spores from virulent strains of Bacillus anthracis and potential surrogates. J Food Prot 2005, 68:2362-2366.

61. Turnbull PC, Frawley DA, Bull RL: Heat activation/shock temperatures for Bacillus anthracis spores and the issue of spore plate counts versus true numbers of spores. J Microbiol Methods 2006. 
62. Scurrah KJ, Robertson RE, Craven HM, Pearce LE, Szabo EA: Inactivation of Bacillus spores in reconstituted skim milk by combined high pressure and heat treatment. J Appl Microbiol 2006, 101:172-180.

63. Leuschner RG, Lillford PJ: Effects of temperature and heat activation on germination of individual spores of Bacillus subtilis. Lett Appl Microbiol 1999, 29:228-232.

64. Bulla LA, St Julian G, Rhodes RA, Hesseltine CW: Scanning electron and phase-contrast microscopy of bacterial spores. Appl Microbiol 1969, 18:490-495.

65. Plomp M, Leighton TJ, Wheeler KE, Malkin AJ: The high-resolution architecture and structural dynamics of Bacillus spores. Biophys J 2005, 88:603-608.

66. Plomp M, Leighton TJ, Wheeler KE, Malkin AJ: Architecture and highresolution structure of Bacillus thuringiensis and Bacillus cereus spore coat surfaces. Langmuir 2005, 21:7892-7898.

67. Plomp M, Leighton TJ, Wheeler KE, Pitesky ME, Malkin AJ: Bacillus atrophaeus outer spore coat assembly and ultrastructure. Langmuir 2005, 21:10710-10716.

68. Zolock RA, Li G, Bleckmann C, Burggraf L, Fuller DC: Atomic force microscopy of Bacillus spore surface morphology. Micron 2006, 37:363-369.

69. Wig A, Arakawa E, Passian A, Thundat T: Photothermal spectroscopy of Bacillus anthracis and Bacillus cereus with microcantilevers. Sensors and Actuators 2004, B114:206-211.

70. Arakawa ET, Lavrik NV, Datskos PG: Detection of anthrax simulants with microcalorimetric spectroscopy: Bacillus subtilis and Bacillus cereus spores. Appl Opt 2003, 42:1757-1762.

71. Stratis-Cullum DN, Griffin GD, Mobley J, Vass AA, Vo-Dinh T: A miniature biochip system for detection of aerosolized Bacillus globigii spores. Anal Chem 2003, 75:275-280.

72. Ulrich MP, Christensen DR, Coyne SR, Craw PD, Henchal EA, Sakai SH, Swenson D, Tholath J, Tsai J, Weir AF, Norwood DA: Evaluation of the Cepheid GeneXpert system for detecting Bacillus anthracis. J Appl Microbiol 2006, 100:1011-1016.

73. Farquharson S, Grigely L, Khitrov V, Smith W, Sperry JF, Fenerty G: Detecting Bacillus cereus spores on a mail sorting system using Raman spectroscopy. Journal Of Raman Spectroscopy 2004, 35:82-86.

74. Radnedge L, Agron PG, Hill KK, Jackson PJ, Ticknor LO, Keim P. Andersen GL: Genome differences that distinguish Bacillus anthracis from Bacillus cereus and Bacillus thuringiensis. Appl Environ Microbiol 2003, 69:2755-2764.

75. Kane SR, Letant SE, Murphy GA, Alfaro TM, Krauter PW, Mahnke R, Legler TC, Raber E: Rapid, high-throughput, culture-based PCR methods to analyze samples for viable spores of Bacillus anthracis and its surrogates. $J$ Microbiol Methods 2009, 76:278-284

76. Saikaly PE, Barlaz MA, de Los Reyes FL: Development of quantitative realtime PCR assays for detection and quantification of surrogate biological warfare agents in building debris and leachate. Appl Environ Microbiol 2007, 73:6557-6565.

77. Yang S, Rothman RE, Hardick J, Kuroki M, Hardick A, Doshi V, Ramachandran P, Gaydos CA: Rapid polymerase chain reaction-based screening assay for bacterial biothreat agents. Acad Emerg Med 2008, 15:388-392.

78. McBride MT, Masquelier D, Hindson BJ, Makarewicz AJ, Brown S, Burris K, Metz T, Langlois RG, Tsang KW, Bryan R, Anderson DA, Venkateswaran KS, Milanovich FP, Colston BW Jr: Autonomous detection of aerosolized Bacillus anthracis and Yersinia pestis. Anal Chem 2003, 75:5293-5299.

79. Hindson BJ, MCBride MT, Makarewicz AJ, Henderer BD, Setlur US, Smith SM, Gutierrez DM, Metz TR, Nasarabadi SL, Venkateswaran KS, Farrow SW, Colston BW Jr, Dzenitis JM: Autonomous detection of aerosolized biological agents by multiplexed immunoassay with polymerase chain reaction confirmation. Anal Chem 2005, 77:284-289.

80. Stachowiak JC, Shugard EE, Mosier BP, Renzi RF, Caton PF, Ferko SM, Van de Vreugde JL, Yee DD, Haroldsen BL, VanderNoot VA: Autonomous microfluidic sample preparation system for protein profile-based detection of aerosolized bacterial cells and spores. Anal Chem 2007, 79:5763-5770

81. Hart SJ, Terray A, Leski TA, Arnold J, Stroud R: Discovery of a significant optical chromatographic difference between spores of Bacillus anthracis and its close relative, Bacillus thuringiensis. Anal Chem 2006, 78:3221-3225
82. Krebs MD, Mansfield B, Yip P, Cohen SJ, Sonenshein AL, Hitt BA, Davis CE: Novel technology for rapid species-specific detection of Bacillus spores. Biomol Eng 2006, 23:119-127.

83. Gibb-Snyder E, Gullett B, Ryan S, Oudejans L, Touati A: Development of size-selective sampling of Bacillus anthracis surrogate spores from simulated building air intake mixtures for analysis via laser-induced breakdown spectroscopy. Appl Spectrosc 2006, 60:860-870.

84. Gottfried JL, De Lucia FC Jr, Munson CA, Miziolek AW: Standoff detection of chemical and biological threats using laser-induced breakdown spectroscopy. App/ Spectrosc 2008, 62:353-363.

85. Munson CA, Gottfried JL, Snyder EG, De Lucia FC Jr, Gullett B, Miziolek AW: Detection of indoor biological hazards using the man-portable laser induced breakdown spectrometer. Appl Opt 2008, 47:G48-57.

86. Snyder EG, Munson CA, Gottfried JL, De Lucia FC Jr, Gullett B, Miziolek A: Laser-induced breakdown spectroscopy for the classification of unknown powders. Appl Opt 2008, 47:G80-87.

87. Laflamme C, Verreault D, Ho J, Duchaine C: Flow cytometry sorting protocol of Bacillus spore using ultraviolet laser and autofluorescence as main sorting criterion. Journal Of Fluorescence 2006, 16:733-737.

88. Hathout Y, Demirev PA, Ho YP, Bundy JL, Ryzhov V, Sapp L, Stutler J, Jackman J, Fenselau C: Identification of Bacillus spores by matrix-assisted laser desorption ionization-mass spectrometry. Appl Environ Microbiol 1999, 65:4313-4319.

89. Hathout Y, Setlow B, Cabrera-Martinez RM, Fenselau C, Setlow P: Small, acid-soluble proteins as biomarkers in mass spectrometry analysis of Bacillus spores. Appl Environ Microbiol 2003, 69:1100-1107.

90. Elhanany E, Barak R, Fisher M, Kobiler D, Altboum Z: Detection of specific Bacillus anthracis spore biomarkers by matrix-assisted laser desorption/ ionization time-of-flight mass spectrometry. Rapid Commun Mass Spectrom 2001, 15:2110-2116.

91. Warscheid B, Fenselau C: Characterization of Bacillus spore species and their mixtures using postsource decay with a curved-field reflectron. Anal Chem 2003, 75:5618-5627.

92. Pribil PA, Patton E, Black G, Doroshenko V, Fenselau C: Rapid characterization of Bacillus spores targeting species-unique peptides produced with an atmospheric pressure matrix-assisted laser desorption/ionization source. J Mass Spectrom 2005, 40:464-474.

93. Castanha ER, Fox A, Fox KF: Rapid discrimination of Bacillus anthracis from other members of the $B$. cereus group by mass and sequence of "intact" small acid soluble proteins (SASPs) using mass spectrometry. J Microbiol Methods 2006, 67:230-240.

94. Dickinson DN, La Duc MT, Haskins WE, Gornushkin I, Winefordner JD, Powell DH, Venkateswaran K: Species differentiation of a diverse suite of Bacillus spores by mass spectrometry-based protein profiling. Appl Environ Microbiol 2004, 70:475-482.

95. Fergenson DP, Pitesky ME, Frank M, Horn JM, Gard EE: Distinguishing Seven Species of Bacillus Spores Using BioAerosol Mass Spectrometry. Lawrence Livermore National Laboratory (LLNL) L, CA: USDOE 2005.

96. Krebs MD, Zapata AM, Nazarov EG, Miller RA, Costa IS, Sonenshein AL, Davis CE: Detection of biological and chemical agents using differential mobility spectrometry (DMS) technology. leee Sensors Journal 2005, 5:696-703.

97. Demirev PA, Feldman AB, Kowalski P, Lin JS: Top-down proteomics for rapid identification of intact microorganisms. Anal Chem 2005, 77:7455-7461.

98. Delvecchio VG, Connolly JP, Alefantis TG, Walz A, Quan MA, Patra G, Ashton JM, Whittington JT, Chafin RD, Liang X, Grewal P, Khan AS, Mujer CV: Proteomic profiling and identification of immunodominant spore antigens of Bacillus anthracis, Bacillus cereus, and Bacillus thuringiensis. Appl Environ Microbiol 2006, 72:6355-6363.

99. Min J, Lee J, Deininger RA: Simple and rapid method for detection of bacterial spores in powder useful for first responders. J Environ Health 2006, 68:34-37, 44, 46.

100. Branch D, Brozik S: Low level detection of a Bacillus anthracis simulant using a love-wave biosensors.Edited by: Technology MSa. Sandia National Laboratories; 2003:33.

101. Helfinstine $S L$, Lavrentovich OD, Woolverton CJ: Lyotropic liquid crystal as a real-time detector of microbial immune complexes. Lett Appl Microbiol 2006, 43:27-32. 
102. Stephens JR: Flourescence cross section meaurements of biological agent simulants. Conference on Obscuration and Aerosol Research Los Alamos National Lab 1996.

103. Sainathrao S, Mohan KV, Atreya C: Gamma-phage lysin PlyG sequencebased synthetic peptides coupled with Qdot-nanocrystals are useful for developing detection methods for Bacillus anthracis by using its surrogates, B. anthracis-Sterne and B. cereus-4342. BMC Biotechnol 2009, 9:67.

104. Stephans JR: Measurements of the Ultraviolet Fluorescence Cross Sections and Spectra of Bacillus Anthracis Simulants.Edited by: Lab LAN 1998.

105. Stephens JR: Identification of BW agents simulants on building surfaces by infrared reflectance spectroscopy. CBW Protection Symposium; May 10 13; Stockholm, Sweden 1998, 11

106. Utrup $\sqcup$, Werner $K$, Frey AH: Minimizing pathogenic bacteria, including spores, in indoor air. J Environ Health 2003, 66:19-26, 29.

107. Lee SA, Willeke K, Mainelis G, Adhikari A, Wang HX, Reponen T, Grinshpun SA: Assessment of electrical charge on airborne microorganisms by a new bioaerosol sampling method. Journal of Occupational And Environmental Hygiene 2004, 1:127-138.

108. Clark Burton N, Adhikari A, Grinshpun SA, Hornung R, Reponen T: The effect of filter material on bioaerosol collection of Bacillus subtilis spores used as a Bacillus anthracis simulant. J Environ Monit 2005, 7:475-480.

109. Lighthart B, Prier K, Bromenshenk J: Detection of aerosolized bacterial spores (Bacillus atrophaeus) using free-flying honey bees (Hymenoptera apidae) as collectors. Aerobiologica 2004, 20:191-195

110. Teschke K, Chow Y, Bartlett K, Ross A, van Netten C: Spatial and temporal distribution of airborne Bacillus thuringiensis var. kurstaki during an aerial spray program for gypsy moth eradication. Environmental Health Perspectives 2001, 109:47-54.

111. Valadares De Amorim G, Whittome B, Shore B, Levin DB: Identification of Bacillus thuringiensis subsp. kurstaki strain HD1-Like bacteria from environmental and human samples after aerial spraying of Victoria, British Columbia, Canada, with Foray 48B. Appl Environ Microbiol 2001, 67:1035-1043.

112. Krauter $P$, Biermann A, Larsen L: Transport efficiency and deposition velocity of fluidized spores in ventilation ducts. Aerobiologia 2005 21:155-172.

113. Dougherty GM, Hadley DR, o'Conner PR: Engineered aerosol production for laboratory scale chemical/biological test and evaluation.Edited by: Energy Do. Lawrence Livermore National Laboratory; 2007:28.

114. Krauter P, Biermann A: Reaerosolization of Fluidized Spores in Ventilation Systems. Appl Environ Microbiol 2007.

115. Scott Duncan EJ, Kournikakis B, Ho J, Hill I: Pulmonary deposition of aerosolized Bacillus atrophaeus in a swine model due to exposure from a simulated anthrax letter incident. Inhalation Toxicology 2009, 21:141-152.

116. Drobniewski FA: Bacillus-Cereus And Related Species. Clinical Microbiology Reviews 1993, 6:324-338.

117. Helgason E, Caugant DA, Olsen I, Kolsto AB: Genetic structure of population of Bacillus cereus and $B$. thuringiensis isolates associated with periodontitis and other human infections. J Clin Microbiol 2000, 38:1615-1622.

118. Green M, Heumann M, Sokolow R, Foster LR, Bryant R, Skeels M: Public health implications of the microbial pesticide Bacillus thuringiensis: an epidemiological study, Oregon, 1985-86. Am J Public Health 1990, 80:848-852.

119. McClintock JT, Schaffer CR, Sjoblad RD: A Comparative Review Of The Mammalian Toxicity Of Bacillus Thuringiensis-Based Pesticides. Pesticide Science 1995, 45:95-105.

120. Samples JR, Buettner H: Ocular Infection Caused By A Biological Insecticide. Journal Of Infectious Diseases 1983, 148:614-614.

121. Hernandez E, Ramisse F, Ducoureau JP, Cruel T, Cavallo JD: Bacillus thuringiensis subsp. konkukian (serotype H34) superinfection: case report and experimental evidence of pathogenicity in immunosuppressed mice. J Clin Microbiol 1998, 36:2138-2139.

122. Jackson SG, Goodbrand RB, Ahmed R, Kasatiya S: Bacillus cereus and Bacillus thuringiensis isolated in a gastroenteritis outbreak investigation. Letters in Applied Microbiology 1995, 21:103-105.

123. Nicholson WL, Munakata N, Horneck G, Melosh HJ, Setlow P: Resistance of Bacillus endospores to extreme terrestrial and extraterrestrial environments. Microbiol Mol Biol Rev 2000, 64:548-572.
124. Ash C, Farrow JAE, Wallbanks S, Collins MD: Phylogenetic Heterogeneity Of The Genus Bacillus Revealed By Comparative-Analysis Of SmallSubunit-Ribosomal Rna Sequences. Letters In Applied Microbiology 1991 13:202-206.

125. Brumlick MJ, Bielawska-Drozd A, Zakowska D, Liang X, Spalletta RA, Patra G, DelVecchio VG: Genetic diversity among Bacillus anthracis, Bacillus cereus and Bacilus thuringiensis strains using repetative element polymorphisms-PCR. Polish Journal of Microbiology 2004, 53:215-225.

126. Burton JE, Oshota OJ, Silman NJ: Differential identification of Bacillus anthracis from environmental Bacillus species using microarray analysis. Journal Of Applied Microbiology 2006, 101:754-763.

127. Fritze D: Taxonomy of the Genus Bacillus and related genera: The aerobic endospore-fromiung bacteria. Phytopathology 2004, 94:1245-1248.

128. Gohar M, Gilois N, Graveline R, Garreau C, Sanchis V, Lereclus D: A comparative study of Bacillus cereus, Bacillus thuringiensis and Bacillus anthracis extracellular proteomes. Proteomics 2005, 5:3696-3711.

129. Han CS, Xie G, Challacombe JF, Altherr MR, Bhotika SS, Bruce D, Campbell CS, Campbell ML, Chen J, Chertkov O, Cleland C, Dimitrijevic M, Doggett NA, Fawcett JJ, Glavina T, Goodwin LA, Hill KK, Hitchcock P, Jackson PJ, Keim P, Kewalramani AR, Longmire J, Lucas S, Malfatti S, McMurry K, Meincke LJ, Misra M, Moseman BL, Mundt M, Munk AC, et al: Pathogenomic sequence analysis of Bacillus cereus and Bacillus thuringiensis isolates closely related to Bacillus anthracis. J Bacterio/ 2006, 188:3382-3390

130. Helgason E, Okstad OA, Caugant DA, Johansen HA, Fouet A, Mock M, Hegna I, Kolsto : Bacillus anthracis, Bacillus cereus, and Bacillus thuringiensis-one species on the basis of genetic evidence. App/ Environ Microbiol 2000, 66:2627-2630.

131. Helgason E, Tourasse NJ, Meisal R, Caugant DA, Kolsto AB: Multilocus sequence typing scheme for bacteria of the Bacillus cereus group. Appl Environ Microbiol 2004, 70:191-201.

132. Hill KK, Ticknor LO, Okinaka RT, Asay M, Blair H, Bliss KA, Laker M, Pardington PE, Richardson AP, Tonks M, Beecher DJ, Kemp JD, Kolsto AB, Wong AC, Keim $P$, Jackson PJ: Fluorescent amplified fragment length polymorphism analysis of Bacillus anthracis, Bacillus cereus, and Bacillus thuringiensis isolates. Appl Environ Microbiol 2004, 70:1068-1080.

133. Ivanova N, Sorokin A, Anderson I, Galleron N, Candelon B, Kapatral V, Bhattacharyya A, Reznik G, Mikhailova N, Lapidus A, Chu L, Mazur M, Goltsman E, Larsen N, D'Souza M, Walunas T, Grechkin Y, Pusch G, Haselkorn R, Fonstein M, Ehrlich SD, Overbeek R, Kyrpides N: Genome sequence of Bacillus cereus and comparative analysis with Bacillus anthracis. Nature 2003, 423:87-91.

134. Jackson PJ, Hill KK, Laker MT, Ticknor LO, Keim P: Genetic comparison of Bacillus anthracis and its close relatives using amplified fragment length polymorphism and polymerase chain reaction analysis. J Appl Microbiol 1999, 87:263-269.

135. Keim P, Kalif A, Schupp J, Hill K, Travis SE, Richmond K, Adair DM, HughJones $M$, Kuske CR, Jackson P: Molecular evolution and diversity in Bacillus anthracis as detected by amplified fragment length polymorphism markers. J Bacteriol 1997, 179:818-824.

136. Keim P, Klevytska AM, Price LB, Schupp JM, Zinser G, Smith KL, HughJones ME, Okinaka R, Hill KK, Jackson PJ: Molecular diversity in Bacillus anthracis. J Appl Microbiol 1999, 87:215-217.

137. Priest FG, Barker M, Baillie LW, Holmes EC, Maiden MC: Population structure and evolution of the Bacillus cereus group. J Bacteriol 2004, 186:7959-7970

138. Rasko DA, Ravel J, Okstad OA, Helgason E, Cer RZ, Jiang L, Shores KA, Fouts DE, Tourasse NJ, Angiuoli SV, Kolonay J, Nelson WC, Kolsto AB, Fraser CM, Read TD: The genome sequence of Bacillus cereus ATCC 10987 reveals metabolic adaptations and a large plasmid related to Bacillus anthracis pXO1. Nucleic Acids Res 2004, 32:977-988.

139. Read TD, Peterson SN, Tourasse N, Baillie LW, Paulsen IT, Nelson KE, Tettelin H, Fouts DE, Eisen JA, Gill SR, Holtzapple EK, Okstad OA, Helgason E, Rilstone J, Wu M, Kolonay JF, Beanan MJ, Dodson RJ, Brinkac LM, Gwinn M, DeBoy RT, Madpu R, Daugherty SC, Durkin AS, Haft DH, Nelson WC Peterson JD, Pop M, Khouri HM, Radune D, et al: The genome sequence of Bacillus anthracis Ames and comparison to closely related bacteria. Nature 2003, 423:81-86.

140. Todd SJ, Moir AJ, Johnson MJ, Moir A: Genes of Bacillus cereus and Bacillus anthracis encoding proteins of the exosporium. J Bacterio/ 2003, 185:3373-3378 
141. Turnbull PC: Definitive identification of Bacillus anthracis-a review. J Appl Microbiol 1999, 87:237-240

142. Valjevac S, Hilaire V, Lisanti O, Ramisse F, Hernandez E, Cavallo JD, Pourcel C, Vergnaud G: Comparison of minisatellite polymorphisms in the Bacillus cereus complex: a simple assay for large-scale screening and identification of strains most closely related to Bacillus anthracis. Appl Environ Microbiol 2005, 71:6613-6623.

143. Xu D, Cote JC: Phylogenetic relationships between Bacillus species and related genera inferred from comparison of $3^{\prime}$ end $16 \mathrm{~S}$ rDNA and $5^{\prime}$ end 16S-23 S ITS nucleotide sequences. Int I Syst Evol Microbiol 2003, 53:695-704

144. Easterday WR, Van Ert MN, Simonson TS, Wagner DM, Kenefic LJ, Allender $C J$, Keim P: Use of single nucleotide polymorphisms in the $p l c R$ gene for specific Identification of Bacillus anthracis. Journal of Clinical Microbiology 2005, 43:1995-1997.

145. Easterday WR, Van Ert MN, Zanecki S, Keim P: Specific detection of bacillus anthracis using a TaqMan mismatch amplification mutation assay. BioTechniques 2005, 38:731-735.

146. Sylvestre $P$, Couture-Tosi E, Mock M: A collagen-like surface glycoprotein is a structural component of the Bacillus anthracis exosporium. Molecular Microbiology 2002, 45:169-178.

147. Rety S, Salamitou S, Garcia-Verdugo I, Hulmes DJ, Le Hegarat F, Chaby R, Lewit-Bentley A: The crystal structure of the Bacillus anthracis spore surface protein BclA shows remarkable similarity to mammalian proteins. J Biol Chem 2005, 280:43073-43078.

148. Knaysi G: The Endospore Of Bacteria. Bacteriol Rev 1948, 12:19-77.

149. Warth AD, Ohye DF, Murrell WG: The composition and structure of bacterial spores. J Cell Biol 1963, 16:579-592.

150. Gerhardt P, Ribi E: Ultrastructure Of The Exosporium Enveloping Spores Of Bacillus Cereus. J Bacteriol 1964, 88:1774-1789.

151. Knaysi G: Further Observations On The Spodogram Of Bacillus Cereus Endospore. J Bacteriol 1965, 90:453-455.

152. Hachisuka Y, Kozuka S, Tsujikawa M: Exosporia and appendages of spores of Bacillus species. Microbiol Immunol 1984, 28:619-624.

153. Charlton S, Moir AJG, Baillie L, Moir A: Characterization of the exosporium of Bacillus cereus. Journal Of Applied Microbiology 1999, 87:241-245.

154. Peng JS, Tsai WC, Chou CC: Surface characteristics of Bacillus cereus and its adhesion to stainless steel. Int J Food Microbiol 2001, 65:105-111.

155. Beaman TC, Pankratz HS, Gerhardt P: Ultrastructure of the Exosporium and Underlying Inclusions in Spores of Bacillus megaterium Strains. J Bacteriol 1972, 109:1198-1209.

156. Koshikawa T, Yamazaki M, Yoshimi M, Ogawa S, Yamada A, Watabe K, Torii M: Surface hydrophobicity of spores of Bacillus spp. Journal of General Microbiology 1989, 135:2717-2722.

157. Sousa JCF, Silva MT, Balassa G: An exosporium-like outer layer in Bacillus subtilis spores. Nature 1976, 263:53-54.

158. Kramer MJ, Roth IL: Ultrastructural Differences In Exosporium Of Sterne And Vollum Strains Of Bacillus Anthracis. Canadian Journal of Microbiology 1968, 14:1297.

159. Knaysi G: On the structure and nature of the endospore in strain C3 of Bacillus cereus. J Bacteriol 1955, 69:130-138.

160. Kojima K, Sato T: Fine Filaments On Outside Of Exosporium Of Bacillus Anthracis Spores. Journal Of Bacteriology 1966, 91:2382.

161. Hachisuka Y, Kuno T: Filamentous appendages of Bacillus cereus spores. Jpn J Microbiol 1976, 20:555-558.

162. Beaman TC, Pankratz HS, Gerhardt P: Ultrastructure of the exosporium and underlying inclusions in spores of Bacillus megaterium strains. J Bacteriol 1972, 109:1198-1209.

163. Sousa JC, Silva MT, Balassa G: An exosporium-like outer layer in Bacillus subtilis spores. Nature 1976, 263:53-54.

164. Driks A: Bacillus subtilis spore coat. Microbiol Mol Biol Rev 1999, 63:1-20.

165. Takamatsu H, Watabe K: Assembly and genetics of spore protective structures. Cell Mol Life Sci 2002, 59:434-444.

166. Bechtel DB, Bulla LA Jr: Electron Microscope Study of Sporulation and Parasporal Crystal Formation in Bacillus thuringiensis. J Bacteriol 1976, 127:1472-1481.

167. Gerhardt P, Pankratz HS, Scherrer R: Fine Structure of the Bacillus thuringiensis Spore. Appl Environ Microbiol 1976, 32:438-440.

168. Smirnova TA, Mikhailov AM, Tyurin VS, Azizbekyan RR: The fine structure of spores and crystals in various Bacillus thuringiensis serotypes. MIKROBIOLOGIYA 1984, 53:455-462.
169. Doyle R, Nedjat-Haiem F, Singh J: Hydrophobic characteristics of Bacillus spores. Current Microbiology 1984, 10:329-332.

170. Zandomeni RO, Fitzgibbon JE, Carrera M, Steubing E, Rogers JE, Sagripanti J-L: Spore Size Comparison Between Several Bacillus Species. Edited by: MD G-CIAPG 2005.

171. Carrera M, Zandomeni RO, Fitzgibbon J, Sagripanti JL: Difference between the spore sizes of Bacillus anthracis and other Bacillus species. J Appl Microbiol 2007, 102:303-312.

172. Lighthart B: Physics of microbial bioaerosols. In Atmosphere Microbial Aerosols. Edited by: Lighthart B, Mohr AJ. New York: Chapman and Hall; 1994:5-27.

173. Cox CS: Physical aspects of bioaerosols. In Bioaerosols handbook. Edited by: Cox CS, Wathes CM. London: Lewis; 1995:15-25.

174. Carrera M, Zandomeni RO, Sagripanti JL: Wet and dry density of Bacillus anthracis and other Bacillus species. J Appl Microbiol 2008, 105:68-77.

175. Jaax NK, Davis KJ, Geisbert TJ, Vogel P, Jaax GP, Topper M, Jahrling PB: Lethal experimental infection of rhesus monkeys with Ebola-Zaire (Mayinga) virus by the oral and conjunctival route of exposure. Arch Pathol Lab Med 1996, 120:140-155.

176. Baweja RB, Zaman MS, Mattoo AR, Sharma K, Tripathi V, Aggarwal A, Dubey GP, Kurupati RK, Ganguli M, Chaudhury NK, Sen S, Das TK, Gade WN, Singh Y: Properties of Bacillus anthracis spores prepared under various environmental conditions. Arch Microbiol 2008, 189:71-79.

177. Sirena S, Scagliosi G: Lavori E Lezioni Originali. Riforma medicia 1894, 2:340-343

178. Szekely Av: Beitrag zur Lebensdauer der Milzbrandsporen. Zeit Hygiene Infectionskrankheiten 1903, 44:359-363.

179. Busson B: Ein beitrag zur Kenntnis der Lebensdauer von Bacterium coli und Milzbrandsporen. Centralbl Bakteriol, Parasitenkd Infektionskr 1911, 58:505-509.

180. Graham-Smith GS: The longevity of dry spores of B. anthracis. Journal of Hygiene 1930, 30:213-215.

181. Minett FC, Dhanda MR: Multiplication of B. anthracis and Cl. chauvei in soil and water. Indian Journal of Veterinary Science and Animal Husbandry 1941, 11:308-328.

182. Novel R, Reh $T$ : De la longevite des spores du Bacillus anthracis et de la conservation des pouvoirs pathogene ei antigene. Schweizerische Zeitschrift fu" r Pathologie und Bakteriologie 1947, 10:180-192.

183. Dearmon IA Jr, Lively DH, Roth NG: Survival time as a rapid method of determining virulence with Bacillus anthracis. J Bacteriol 1956, 72:666-672.

184. Dearmon IA Jr, Orlando MD, Rosenwald AJ, Klein F, Fernelius AL, Lincoln RE, Middaugh PR: Viability and estimation of shelf-life of bacterial populations. Appl Microbiol 1962, 10:422-427.

185. Wilson JB, Russell KE: Isolation Of Bacillus Anthracis From Soil Stored 60 Years. J Bacteriol 1964, 87:237-238.

186. Lewis JC: Dormancy. In The Bacterial Spore. Edited by: Hurst A, Gould GW. London: Academia Press; 1969:1:301-358.

187. Roberts TA, Hitchins AD: Resistance of spores. In The Bacterial Spore. Edited by: Gould GW, Hurst A. London: Academic Press; 1969:1:611-670.

188. Van Ness GB: Ecology of anthrax. Science 1971, 172:1303-1307.

189. Manchee RJ, Broster MG, Melling J, Henstridge RM, Stagg AJ: Bacillus anthracis on Gruinard Island. Nature 1981, 294:254-255.

190. Dragon DC, Rennie RP: The ecology of anthrax spores: tough but not invincible. Can Vet J 1995, 36:295-301.

191. Pinnock DE, Brand RJ, Milstead JE: The field persistence of Bacillus thuringiensis spores. Journal of Invertebrate Pathology 1971, 18:405.

192. Reynolds CM, Ringelberg DB: Non-indigenous endospore persistence following release in a snow - soil system. Cold Regions Science and Technology 2008, 52:146-154.

193. Pinnock DE, Brand RJ, Jackson KL, Milstead JE: The field persistence of Bacillus thuringiensis spores on Cercis occidentalis leaves. Journal of Invertebrate Pathology 1974, 23:341.

194. Pruett CJH, Burges HD, Wyborn CH: Effect of exposure to soil on potency and spore viability of Bacillus thuringiensis. Journal of Invertebrate Pathology 1980, 35:168.

195. West AW, Burges HD, Wyborn CH: Effect of incubation in natural and autoclaved soil upon potency and viability of Bacillus thuringiensis. Journal of Invertebrate Pathology 1984, 44:121.

196. Petras SF, Casida LE: Survival of Bacillus thuringiensis Spores in Soil. Appl Environ Microbiol 1985, 50:1496-1501. 
197. West AW, Burges HD, Dixon TJ, Wyborn CH: Effect Of Incubation In NonSterilized And Autoclaved Arable Soil On Survival Of BacillusThuringiensis And Bacillus-Cereus Spore Inocula. New Zealand Journal Of Agricultural Research 1985, 28:559-566.

198. West AW, Burges HD, Dixon TJ, Wyborn CH: Survival Of BacillusThuringiensis And Bacillus-Cereus Spore Inocula In Soil - Effects Of Ph, Moisture, Nutrient Availability And Indigenous Microorganisms. Soil Biology \& Biochemistry 1985, 17:657-665.

199. Smith RA, Barry JW: Environmental persistence of Bacillus thuringiensis spores following aerial application. J Invertebr Pathol 1998, 71:263-267.

200. Murray TJ: Thermal death point II. Spores of Bacillus anthracis. Journal of Infectious Diseases 1931, 48:457-467.

201. Curran HR, Evans FR: The Viability of Heat-activatable Spores in Nutrient and Nonnutrient Substrates as Influenced by Prestorage or Poststorage Heating and Other Factors. J Bacteriol 1947, 53:103-113.

202. Stein CB: Some observations on the tenacity of Bacillus anthracis. Veterinary Medicine 1947, 42:13-22.

203. Evans FR, Curran HR: Influence of preheating, $\mathrm{pH}$, and holding temperature upon viability of bacterial spores stored for long periods in buffer substrates. J Bacteriol 1960, 79:361-368.

204. Walker HW, Matches JR, Ayres JC: Chemical composition and heat resistance of some aerobic bacterial spores. J Bacteriol 1961, 82:960-966.

205. Marquis RE, Bender GR: Mineralization and heat resistance of bacterial spores. J Bacteriol 1985, 161:789-791.

206. Moussa-Boudjemaa B, Gonzalez J, Lopez M: Heat resistance of Bacillus cereus spores in carrot extract acidified with different acidulants. Food Control 2006, 17:819.

207. Xu S, Labuza TP, Diez-Gonzalez F: Thermal inactivation of Bacillus anthracis spores in cow's milk. Appl Environ Microbiol 2006, 72:4479-4483.

208. Fernelius AL, Wilkes CE, Dearmon IA Jr, Lincoln RE: A probit method to interpret thermal inactivation of bacterial spores. J Bacteriol 1958, 75:300-304.

209. Lemieux P, Wood J, Lee C, Serre S: Thermal destruction of CB contaminants bound on building materials experiements and modeling. Scientific Conference on Chemical and Biological Defense Research; Timonium, MD 2005, 1-9.

210. Islam MS, Inoue A, Igura N, Shimoda M, Hayakawa I: Inactivation of Bacillus spores by the combination of moderate heat and low hydrostatic pressure in ketchup and potage. Int J Food Microbiol 2006, 107:124-130.

211. van Asselt ED, Zwietering MH: A systematic approach to determine global thermal inactivation parameters for various food pathogens. Int I Food Microbiol 2006, 107:73-82.

212. Mitscherlich E, Marth EH: Microbial Survival in the Environment Berlin: Springer 1984

213. Hilgren J, Swanson KM, Diez-Gonzalez F, Cords B: Susceptibilities of Bacillus subtilis, Bacillus cereus, and avirulent Bacillus anthracis spores to liquid biocides. J Food Prot 2009, 72:360-364.

214. Sokurova EN, Meisel MN: The combined action of ultra-violet and x-rays on the spores of Bacillus anthracis. Biophysics (USSR)(English Translation) 1958, 4:474-477.

215. Kenar L, Ortatatli M, Yaren H, Karayilanoglu T, Aydogan H: Comparative sporicidal effects of disinfectants after release of a biological agent. Military Medicine 2007, 172:616-621.

216. Pribil W, Gehringer P, Eschweiler H, Cabaj A, Haider T, Sommer R: Assessment of Bacillus subtilis spores as a possible bioindicator for evaluation of the microbicidal efficacy of radiation processing of water. Water Environ Res 2007, 79:720-724.

217. Van Ert MN, Easterday WR, Simonson TS, U'Ren JM, Pearson T, Kenefic LJ, Busch JD, Huynh LY, Dukerich M, Trim CB, Beaudry J, Welty-Bernard A Read T, Fraser CM, Ravel J, Keim P: Strain-Specific Single-Nucleotide Polymorphism Assays for the Bacillus anthracis Ames Strain. J Clin Microbiol 2007, 45:47-53.

218. Vogler AJ, Driebe EM, Lee J, Auerbach RK, Allender CJ, Kubota K, Andersen GL, Radnedge L, Worsham PL, Keim P, Wagner DM: Rapid and specific identification of North American Yersinia pestis and the common laboratory strain, CO92. BioTechniques 2008, 44:201-207.

219. Agoston R, Soni KA, McElhany K, Cepeda ML, Zuckerman U, Tzipori S, Mohacsi-Farkas C, Pillai SD: Rapid concentration of Bacillus and Clostridium spores from large volumes of milk, using continuous flow centrifugation. J Food Prot 2009, 72:666-668.
220. Carey LF, St Amant DC, Guelta MA: Production of Bacillus Spores as a Simulant for Biological Warfare Agents.Edited by: Army. EDGEWOOD CHEMICAL BIOLOGICAL CENTER ABERDEEN PROVING GROUND MD; 2004:40.

221. Burton JE, Oshota OJ, North E, Hudson MJ, Polyanskaya N, Brehm J, Lloyd G, Silman NJ: Development of a multi-pathogen oligonucleotide microarray for detection of Bacillus anthracis. Mol Cell Probes 2005, 19:349-357.

222. Farnsworth JE, Goyal SM, Kim SW, Kuehn TH, Raynor PC, Ramakrishnan MA, Anantharaman S, Tang WH: Development of a method for bacteria and virus recovery from heating, ventilation, and air conditioning (HVAC) filters. Journal Of Environmental Monitoring 2006, 8:1006-1013.

223. Knudson GB: Photoreactivation of ultraviolet-irradiated, plasmid-bearing, and plasmid-free strains of Bacillus anthracis. Appl Environ Microbiol 1986, 52:444-449.

224. Galeano B, Korff E, Nicholson WL: Inactivation of vegetative cells, but not spores, of Bacillus anthracis, B-cereus, and B-subtilis on stainless steel surfaces coated with an antimicrobial silver- and zinc-containing zeolite formulation. Applied And Environmental Microbiology 2003, 69:4329-4331.

225. Montville TJ: Thermal Resistance of Bacillus anthracis Spores and Surrogates. Proceedings of The Institute of Food Technologists' First Annual Food Protection and Defense Research Conference Atlanta, Georgia 2005.

226. De Siano T, Padhi S, Schaffner DW, Montville TJ: Growth characteristics of virulent Bacillus anthracis and potential surrogate strains. J Food Prot 2006, 69:1720-1723.

227. Levin DB, Valadares de Amorim G: Potential for aerosol dissemination of biological weapons: lessons from biological control of insects. Biosecur Bioterror 2003, 1:37-42.

228. Levin D: Monitering human exposure to Bacillus thuringiensis after spray. 2004.

229. Perez A, Hohn C, Higgins J: Filtration methods for recovery of Bacillus anthracis spores spiked into source and finished water. Water Res 2005, 39:5199-5211.

doi:10.1186/2041-2223-1-4

Cite this article as: Greenberg et al:: Identifying experimental surrogates

for Bacillus anthracis spores: a review. Investigative Genetics 2010 1:4.

\section{Submit your next manuscript to BioMed Central and take full advantage of:}

- Convenient online submission

- Thorough peer review

- No space constraints or color figure charges

- Immediate publication on acceptance

- Inclusion in PubMed, CAS, Scopus and Google Scholar

- Research which is freely available for redistribution 